\title{
Relationship of databases of live births and infant deaths for analysis of congenital malformations
}

Aline Luzia Sampaio Guimarães 1

https://orcid.org/0000-0001-5752-8373

Celivane Cavalcanti Barbosa 2

https://orcid.org/0000-0001-8405-0432

Conceição Maria de Oliveira 3

https://orcid.org/0000-0002-2220-5782

Lívia Teixeira de Souza Maia 4

https://orcid.org/0000-0002-0161-7729

Cristine Vieira do Bonfim 5

iD https://orcid.org/0000-0002-4495-9673

1,2 Secretaria do Estado de Pernambuco. Recife, PE, Brasil.

3 Departamento de Saúde. Centro Universitário Maurício de Nassau. Recife, PE, Brasil

4 Centro Acadêmico de Vitória. Universidade Federal de Pernambuco. Vitória de Santo Antão, PE, Brasil.

5 Fundação Joaquim Nabuco. Diretoria de Pesquisas Sociais. Rua Dois Irmãos 92. Ed. Anexo Anízio Teixeira. Recife, PE, Brasil. CEP: 52.071-440.

E-mail: cristine.bonfim@uol.com.br

\begin{abstract}
Objectives: to describe the prevalence of congenital malformations in live births in Recife, based on the relationship of birth and infant death data.

Methods: a cross-sectional study with data from the Live Birth Information System (Sinasc) and Mortality (MIS) of residents in Recife-PE between 2013 and 2015. The deterministic linkage of deaths and live births (LB) with malformation and the prevalence rate were calculated.

Results: 545 (95.1\%) deaths and live births were matched. According to the Sinasc, the prevalence of congenital malformations was 10.4 per 1,000 LB. After the linkage, the rate was 12.4. Malformations of the musculoskeletal system (42.1\%) among live births were highlighted, as well as malformations of the circulatory system (35.3\%) found in infant deaths.

Conclusions: linkage increased the prevalence of congenital malformations in the studied cohort. This demonstrates the potential of this strategy for the monitoring of congenital malformations, which can be used to monitor infant death.
\end{abstract}

Key words Congenital abnormalities, Vital statistics, Infant mortality, Information systems

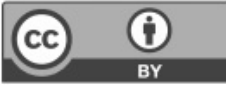




\section{Introduction}

Child mortality is closely related to biological, socioeconomic, cultural factors, health service delivery and the quality of care in maternal and child health care. ${ }^{1}$ One of the main causes that influence these deaths is congenital malformations. ${ }^{2}$

These malformations take place because of alterations in embryonic development resulting in morphological, functional or structural abnormalities, which may or may not be apparent at birth, ${ }^{3}$ caused by genetic, environmental or unknown origin changes. ${ }^{4}$ About 2 to $5 \%$ of live births worldwide, have some birth defects, detected at birth or later, such as congenital heart defects and urinary tract malformations. 5

The overall infant mortality rate (IMR) from 1990 to 2016 dropped from 93 to 41 deaths per 1,000 live births (LB), representing a decline of 53\%.6 Between 1990 and 2014, Brazil's IMR decreased, from 47.1 to 14.1 deaths per 1,000 LB $(70 \%$ decrease). ${ }^{7}$ However, studies show a reduction in IMR and an increase in the proportion of infant deaths from congenital malformation. 2,9

Congenital malformations are a major cause of death in several countries.5,9 In the Americas, they are the second leading cause of death in newborns. 10 In Brazil, they are the second cause of death in infants in all regions of the country, accounting for $22 \%$ of child deaths. 7

Until the late 1990s, data on malformations were obtained from the Declarations of Death (DD), form from the Mortality Information System (MIS) that was implemented in 1975 by the Brazilian Ministry of Health (MH). In 1990, the Live Birth Information System (Sinasc) was created, which has as a standard document the Live Birth Declaration (LBD). However, only in 1999 a specific field was included in this instrument for recording congenital malformations, making Sinasc an important tool for its monitoring. ${ }^{11}$

In Brazil, the implementation of both systems, MIS and Sinasc, and the presence of the key variable, made it possible to use the linkage technique between these databases for studies related to child mortality. ${ }^{12}$ The use of linkage consists in linking two or more independent data sources, which have the characteristic of having variables in common. ${ }^{8}$ Thus, it is possible to identify records of the same individual that is part of two or more information systems. 13

Linkage is increasingly applied in health research because it improves the quality of information, with the advantage of low operating cost.12 In studies on child mortality, the use of linkage has enabled the analysis of risk factors associated with mortality, evidencing that biological variables increase the chance of death; 14 assessing the completeness and agreement of information on infant deaths by demonstrating better completeness in the information systems (99 to $100 \%$ ); 13 estimating the prevalence of congenital anomalies in live births; infant deaths ${ }^{9}$ and investigate the validity of birth registration diagnoses compared with information from a birth defect surveillance program. ${ }^{15}$

The linkage technique makes it possible to analyze in more details information on congenital malformation. Thus, underreporting can be reduced and reliable estimates of the prevalence of a given site can be drawn, as well as the planning of health actions for live births with congenital malformations. This study aims to describe the prevalence of congenital malformations in a cohort of live births in Recife, based on the relationship between birth and infant death data.

\section{Methods}

This is a cross-sectional epidemiological study conducted in Recife, capital of the state of Pernambuco. The city occupies an area of 218,435 $\mathrm{km}^{2}$, divided into 94 districts which, in turn, are distributed in eight Health Districts (HD). It has an estimated population of 1,617,183 inhabitants, with a demographic density of 7,039.64 inhabitants / $\mathrm{km}^{2} .16$

The data source consisted of MIS and Sinasc banks, provided by Recife Health Department. The population consisted of a cohort of live births of mothers living in Recife, whose birth occurred from $01 / 01 / 2013$ to $12 / 31 / 2014$, and of child deaths from this cohort, from $01 / 01 / 2013$ to $31 / 12 / 2015$ (one more year was included for follow-up of live births of 2014) that presented congenital malformation. 242 deaths were excluded because they were live births from 2012 and 2015 (outside the analyzed period)

The linkage of DD with the respective LBD was performed in the program The $R$ Project for Statistical Computing version 3.4.3. For the deterministic linkage, the LBD number was selected as the key variable, as it is unique for each live birth and in DD there is a specific field for its completion. In order to confirm the true pairs, the variables "mother's name", "gender", "birth weight" and "date of birth" were used for manual review. In the relationship of data not paired by LBD number, the manual search was performed with the following 
variables: "mother's name", "gender", "birth weight", "date of birth" and "address of residence".

In the categorization of congenital malformations presented by newborns, we used the classification described by the International Code of Diseases (ICD) - $10^{\text {th }}$ revision, according to Chapter XVII, entitled "Congenital malformations, deformities and chromosomal anomalies".

The completion of fields six (if any congenital anomaly was detected) and 41 (describing all congenital anomalies observed) of LBD were evaluated. Prevalence rates (number of live births with malformation / total live births in the same period $\mathrm{x}$ 1000 live births) of malformations were calculated, according to information from Sinasc.

With the linked databases were selected the DDs that presented some congenital malformation, described in field 40 (basic and associated causes of death) and compared with the respective LBD. The prevalence (before and after the linkage) of congenital malformations for the study period was calculated, as well as the specific prevalence according to devices or systems affected in the cohort survivors and deaths.

The research was approved by the Research Ethics Committee of the Joaquim Nabuco Foundation (CAEE: 68401517.5.0000.5619) on June 20, 2016.

\section{Results}

We recorded 46,705 live births in Sinasc and 573 deaths of children less than one year of age in MIS in the studied periods. In Sinasc, it was verified the filling of field six (detects any congenital malformation) of LBD in 46,688 (99.9\%) live births. There were $485(1.0 \%)$ records of congenital malformation, highlighting the deformities of the musculoskeletal system $(42.1 \%)$ with a rate of 4.4 per 1,000 LB (Table 1).

Linkage verified the pairing of $510(89.0 \%)$ DD with their respective LBD. After a manual search, 35 records were recovered, with the identification of $545(95.1 \%)$ true pairs (DD / LBD). A total of 184 (33.8\%) infant deaths had malformations, with 97 $(52.7 \%)$ in the DD, $4(2.2 \%)$ in the LBD and 83 $(45.1 \%)$ in the DD and LBD (Figure 1).

Linkage recovered 97 cases of congenital malformation for Sinasc, totaling 582 live births with malformations (485 in LBD + 97 in DD). The prevalence rate for malformations of live births, according to the Sinasc, was 10.4 per $1,000 \mathrm{LB}$. After data correction by MIS, it was 12.4 per 1,000 $\mathrm{LB}$, and the prevalence of congenital malformations increased by $20.0 \%$ after linkage (Table 2 ).

Regarding deaths with congenital malformation, the prevalence rate was 3.9 per 1,000 LB. The main cause was that of the circulatory system $(n=65$; $35.3 \%$ ), totaling 1.4 per 1,000 LB (Table 3 ). After linkage, there was an increase of $169.0 \%$ in the malformations of the circulatory system, which in principle were 29 cases, and 49 were added (Table $4)$.

\section{Discussion}

Linking the bases of live births and infant deaths allowed the identification of cases other than those reported in Sinasc and increased the prevalence rate by $20 \%$. This fact shows that the study of malformations requires a multiple source approach.

MIS is an information system that has proved indispensable for retrieving data on malformations in live births. This result can be explained by the fact that microsomal malformations and non-apparent chromosomal anomalies require more accurate diagnosis over a long period of time, resulting in late diagnosis, and are likely to be identified, posteriorly, in the DD.16 This information shows the importance of using both databases simultaneously.

In this study, the availability of information in Sinasc can be considered good, since the absence of record on congenital malformations was $0.1 \%$ (ignored and blank). A study that evaluated Sinasc nationwide between 2006-2010 showed that the absence of this variable was $1.5 \% .17$ Access to these LBD data allows the characterization of the prevalence of different types of congenital malformations. Epidemiological data from Sinasc contribute to the planning and implementation of health programs and policies that meet the needs of live births with malformations. 18

A study evaluating the sensitivity and accuracy of congenital malformations recorded in Florida-US birth certificate revealed low sensitivity $(19.1 \%)$, with a variation of $55 \%$ for anencephaly and $10 \%$ for other defects. In addition, $54.9 \%$ of the diagnoses were false positives. ${ }^{19}$ One of the obstacles pointed out is the completion of statements by various professionals such as physician, nurse, midwife, and civil authority, which results in the variation of the described information. ${ }^{16,19}$

Other studies have also demonstrated the contribution of linkage of live birth and infant death bases to the specification of the prevalence of malformations. In Mexico, the prevalence rate of down syndrome obtained by the birth information subsystem differed from that presented by the birth 
Table 1

Frequency and prevalence rate (per 1,000 LB) of congenital malformations for live births according to information from the Live Birth Information System (SINASC). Recife, 2013 and 2014.

\begin{tabular}{lccc}
\hline Congenital malformations & \multicolumn{2}{c}{ Live births } \\
\cline { 2 - 4 } & $\mathrm{n}$ & $\%$ & Prevalence \\
\hline $\begin{array}{l}\text { Of the nervous system } \\
\text { (Q00 - Q07) }\end{array}$ & 33 & 6.8 & 0.7 \\
Eye, ear, face, neck & 31 & 6.4 & 0.7 \\
(Q10 - Q18) & & & \\
Of the circulatory system & 29 & 6.0 & 0.6 \\
(Q20 - Q28) & & & \\
Of the respiratory system & 9 & 1.9 & 0.2 \\
(Q30 - Q34) & 20 & 4.1 & 0.4 \\
Cleft lip and cleft palate & & & \\
(Q35 - Q37) & 17 & 3.5 & 1.2 \\
Other congenital malformations of the digestive tract \\
(Q38 - Q45)
\end{tabular}

Source: GEVEPI/SEVS/SIM/Sinasc

Total: 46.705 live births - cohort.

\section{Figure 1}

Linkage between Live Birth Information System (Sinasc) and Mortality Information System (MIS).

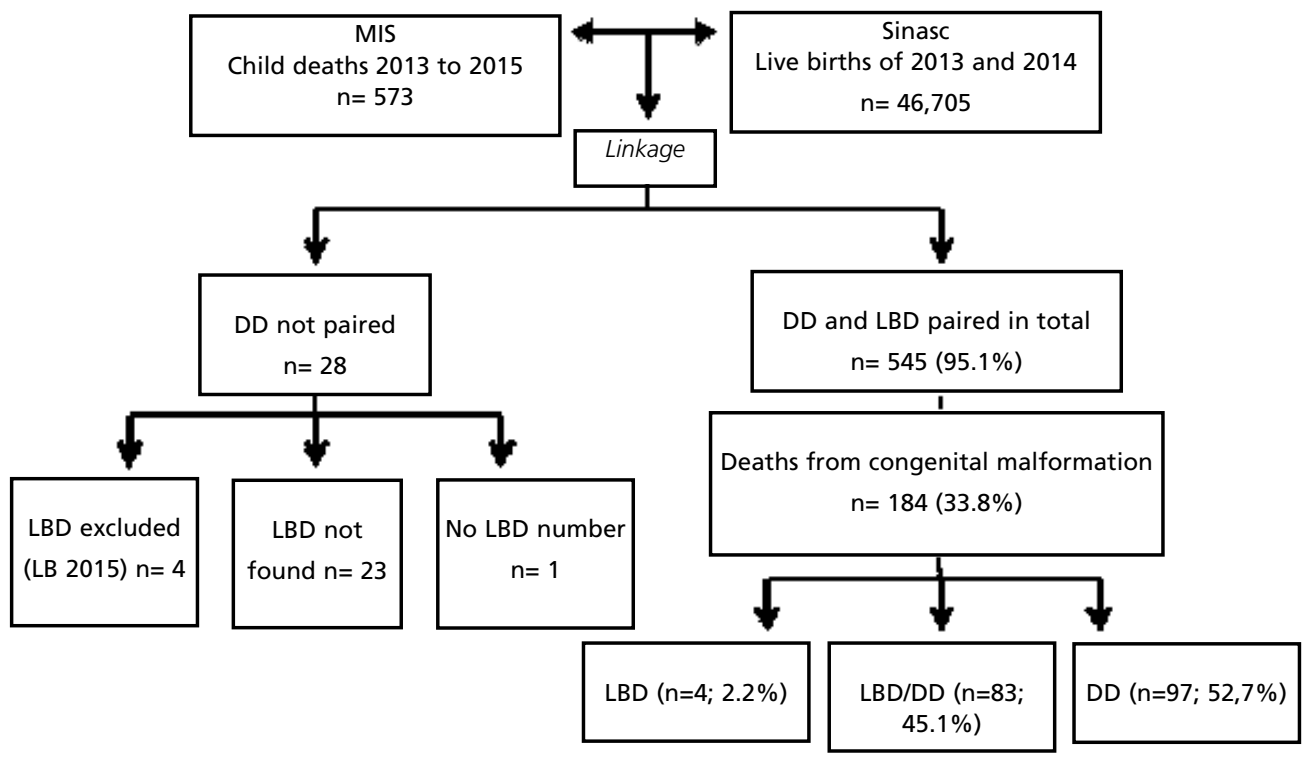




\section{Table 2}

Frequency and prevalence rate (per 1,000 LB) of congenital malformations for Live Birth Information Systems (Sinasc) and Mortality (MIS), pre and post-linkage of databases. Recife, 2013 to 2015.

\begin{tabular}{lcccccccc}
\hline \multirow{2}{*}{ Source } & \multicolumn{3}{c}{ Pre-linkage } & \multicolumn{3}{c}{ Post-linkage } & \multicolumn{2}{c}{ Increment } \\
\cline { 2 - 9 } & $\mathrm{n}$ & $\%$ & Prevalence & $\mathrm{n}$ & $\%$ & Prevalence & $\mathrm{n}$ & $\%$ \\
\hline MIS & 180 & 33.0 & 3.8 & 184 & 33.7 & 3.9 & 4 & 2.2 \\
Sinasc & 485 & 1.0 & 10.4 & 582 & 1.2 & 12.4 & 97 & 20.0
\end{tabular}

Source: GEVEPI/SEVS/SIM/SinasC

Total: 46,705 live births - cohort/ 545 child deaths.

Table 3

Frequency and prevalence rate (per 1,000 LB) of congenital malformations recorded for cohort deaths. Recife, 2013 to 2015.

\begin{tabular}{|c|c|c|c|}
\hline \multirow[t]{2}{*}{ Congenital malformations } & \multicolumn{3}{|c|}{ Deaths } \\
\hline & $\mathrm{n}$ & $\%$ & Prevalence \\
\hline \multicolumn{4}{|l|}{ Of the nervous system } \\
\hline (Q00 - Q07) & 19 & 10.3 & 0.4 \\
\hline \multicolumn{4}{|l|}{ Eye, ear, face, neck } \\
\hline (Q10 - Q18) & 2 & 1.1 & - \\
\hline \multicolumn{4}{|l|}{ Of the circulatory system } \\
\hline (Q20 - Q28) & 65 & 35.3 & 1.4 \\
\hline \multicolumn{4}{|l|}{ Of the respiratory tract } \\
\hline (Q30 - Q34) & 9 & 4.9 & 0.2 \\
\hline \multicolumn{4}{|l|}{ Cleft lip and cleft palate } \\
\hline (Q35 - Q37) & 1 & 0.5 & - \\
\hline \multicolumn{4}{|l|}{ Of the digestive system } \\
\hline (Q38 - Q45) & 9 & 4.9 & 0.2 \\
\hline \multicolumn{4}{|l|}{ Of the genital organs } \\
\hline (Q50 - Q56) & 1 & 0.5 & - \\
\hline \multicolumn{4}{|l|}{ Of the urinary tract } \\
\hline (Q60 - Q64) & 5 & 2.7 & 0.1 \\
\hline \multicolumn{4}{|l|}{ Of the musculoskeletal system } \\
\hline (Q65- Q79) & 23 & 12.5 & 0.5 \\
\hline \multicolumn{4}{|c|}{ Other congenital malformations } \\
\hline (Q80 - Q89) & 22 & 12.1 & 0.5 \\
\hline \multicolumn{4}{|c|}{ Chromosomal anomalies, not elsewhere classified } \\
\hline (Q90 - Q99) & 28 & 15.2 & 0.6 \\
\hline Total 184 & 100.0 & 3.9 & \\
\hline
\end{tabular}

Source: GEVEPI/SEVS/SIM/SinasC

Total: 46,705 live births - cohort / 545 child deaths. 
Table 4

Frequency and prevalence rate (per 1,000 LB) of congenital malformations for the Live Birth Information System, pre and post linkage of databases. Recife, 2013 to 2015.

\begin{tabular}{|c|c|c|c|c|c|c|c|c|}
\hline \multirow[t]{3}{*}{ Congenital malformations } & \multicolumn{6}{|c|}{ Live births } & & \\
\hline & \multicolumn{3}{|c|}{ Pre-linkage } & \multicolumn{3}{|c|}{ Post-linkage } & \multicolumn{2}{|c|}{ Increment } \\
\hline & $n$ & $\%$ & Prevalence & $n$ & $\%$ & Prevalence & $\mathrm{n}$ & $\%$ \\
\hline \multicolumn{9}{|l|}{ Of the nervous system } \\
\hline (Q00 - Q07) & 33 & 6.8 & 0.7 & 40 & 6.9 & 0.8 & 7 & 21.2 \\
\hline \multicolumn{9}{|l|}{ Eye, ear, face, neck } \\
\hline (Q10 - Q18) & 31 & 6.4 & 0.7 & 31 & 5.3 & 0.7 & - & - \\
\hline \multicolumn{9}{|l|}{ Of the circulatory system } \\
\hline (Q20 - Q28) & 29 & 6.0 & 0.6 & 78 & 13.4 & 1.7 & 49 & 169.0 \\
\hline \multicolumn{9}{|l|}{ Of the respiratory tract } \\
\hline$(\mathrm{Q} 30-\mathrm{Q} 34)$ & 9 & 1.9 & 0.2 & 9 & 1.5 & 0.2 & - & - \\
\hline \multicolumn{9}{|l|}{ Cleft lip and cleft palate } \\
\hline (Q35 - Q37) & 20 & 4.1 & 0.4 & 20 & 3.4 & 0.4 & - & - \\
\hline \multicolumn{9}{|l|}{ Of the digestive system } \\
\hline (Q38 - Q45) & 17 & 3.5 & 0.4 & 23 & 4.0 & 0.5 & 6 & 35.2 \\
\hline \multicolumn{9}{|l|}{ Of the genital organs } \\
\hline$(\mathrm{Q} 50-\mathrm{Q} 56)$ & 56 & 11.6 & 1.2 & 56 & 9.6 & 1.2 & - & - \\
\hline \multicolumn{9}{|l|}{ Of the urinary tract } \\
\hline (Q60 - Q64) & 7 & 1.4 & 0.1 & 10 & 1.7 & 0.2 & 3 & 42.8 \\
\hline \multicolumn{9}{|l|}{ Of the musculoskeletal system } \\
\hline (Q65- Q79) & 204 & 42.1 & 4.4 & 213 & 36.6 & 4.5 & 9 & 4.4 \\
\hline Other malformations (Q80 - Q89) & 18 & 3.7 & 0.4 & 26 & 4.5 & 0.5 & 8 & 44.4 \\
\hline \multicolumn{9}{|l|}{ Chromosomal anomalies, not } \\
\hline elsewhere classified (Q90 - Q99) & 21 & 4.3 & 0.4 & 36 & 6.2 & 0.8 & 15 & 71.4 \\
\hline Multiple malformations & 40 & 8.2 & 0.9 & 40 & 6.9 & 0.9 & - & - \\
\hline Total & 485 & 100.0 & 10.4 & 582 & 100.0 & 12.4 & 97 & 20.0 \\
\hline
\end{tabular}

Source: GEVEPI/SEVS/SIM/Sinasc

Total: 46,705 live births - cohort.

defects surveillance program due to difficulty of clinical diagnosis in the neonatal period. 10

The use of the infant death certificate to monitor birth defects in the United States made it possible to locate cases that would otherwise have been missed, demonstrating the contribution of this source of information to prevalence. ${ }^{20}$ In the city of São Paulo (SP), the application of the linkage technique resulted in a correction of $14.3 \%$ in the prevalence rate of birth defects and in this study, it was of $20 \% .21$

The prevalence rates found are similar to other studies, such as in São Paulo, which was 17.9 per $1,000 \mathrm{LB}^{22}$ and in Rio Grande do Norte, in which it was 3.18 per 1,000 LB among deaths. ${ }^{23}$ In Joinville$\mathrm{SC}$, an analysis of risk factors for infant mortality was performed, and it was found that the variable presence of congenital anomaly increased the likelihood of death. 15 As health indicators improved with the reduction of preventable child mortality (infectious, parasitic, nutritional and respiratory diseases), malformations influence IMR and are characterized as a public health problem. They need special attention in order to prevent and reduce morbidity and mortality. 2,23

The study results showed malformations of the musculoskeletal system as the most prevalent among live births. Other studies have also observed a predominance of musculoskeletal system involvement, such as: in the municipalities of Fortaleza-CE (30\%), São Paulo-SP (29.93\%) and São Luís-MA $(48 \%) .22,24,25$ The ease of diagnosis of musculoskeletal malformations may explain these results. These are macrosomal malformations, visible and detectable on physical examination, diagnosed early in the immediate postnatal period. 22

Among the deaths, the malformations of the circulatory system stand out. Noteworthy is the 
recovery of these causes for Sinasc after linkage (increase of 169.0\%). In Rio de Janeiro, there was an underreporting of congenital heart disease in Sinasc when compared to MIS. This may be related to the difficulty of diagnosis during prenatal care or shortly after birth, especially in cases of minor heart disease. 26

From the link between the death and live births database, information related to birth defects has been retrieved and can be used in birth defect surveillance programs that many countries already have, but still needs to be implemented in routine surveillance of child death in Brazil, since investigations of congenital malformations are optional due to the lower potential for avoidability.

The World Health Organization has established basic actions for the establishment of national surveillance programs aimed at preventing and caring for congenital malformations. ${ }^{3}$ Reliable and timely information on malformations can contribute to the identification of teratogens, prevalence estimates, epidemiological profiles and timely referral to reference services to improve the quality of life of these children. 4,27

Congenital Malformation Surveillance Programs are implemented in several countries. 10,27,28 Mexico has a Congenital Malformations Registration and Epidemiological Surveillance (RYVEMCE) program established in 1978, comprising 21 hospitals and 11 cities, covering approximately $3.5 \%$ of births. $10 \mathrm{In}$ the United States, 43 states have a population-based surveillance system for birth defects, covering about $80 \%$ of live births. 29

In South America, in 1967, the Latin American Collaborative Study of Congenital Malformations (ECLAMC) was created to act as a research program

\section{References}

1. Mari G, Bursac Z, Goedecke PJ, Dhanireddy R. Factors Associated With Improvements in Mortality and Morbidity Rates of Very- Low-Birth-Weight Infants : a Cohort Study. Glob Pediatr Heal [Internet]. 2018 Jan 6; 5: 2333794X1876536. Disponível em: http://journals. sagepub.com/doi/10.1177/2333794X18765366.

2. Bronberg R, Schuler-Faccini L, Ramallo V, Alfaro E, Dipierri J. Spatial and temporal analysis of infant mortality from congenital malformations in Brazil (1996-2010). J Community Genet [Internet]. 2014 Jul 1; 5 (3): 269-82. Disponível em: http://link.springer.com/10.1007/s12687013-0170-0.

3. WHO (World Health Organization). Congenital Anomalies [Internet]. 2015. Disponível em: http://www.who.int/en/ news-room/fact-sheets/detail/congenital-anomalies.

4. Toufaily MH, Westgate MN, Lin AE, Holmes LB. Causes for congenital anomalies and also as a system for epidemiological surveillance. The network currently consists of 35 hospitals in Chile, Argentina, Bolivia, Brazil, Peru, Venezuela and Colombia. ${ }^{30}$ In Europe there is a network of population records for the epidemiological surveillance of congenital anomalies (EUROCAT) which was established in 1979 and covers $29 \%$ of European population of live births. 28

The study has limits arising from the use of secondary data from MIS and Sinasc without consultation on hospital records, but linkage was an important tool in retrieving information. Linkage increased the overall prevalence of malformations in the cohort studied. Among live births, we highlight those of the musculoskeletal system, and in deaths, there was a predominance of the circulatory system.

The linking of MIS and Sinasc databases made it possible to better monitor congenital malformations. Thus, the use of linkage in the routine of health surveillance services is suggested, as it will allow the retrieval of information in vital statistics systems, facilitate planning studies, monitoring prevalence and its magnitude in the population of live births.

\section{Author's contribution}

All authors participated in the study design, data analysis, interpretation of results, text writing, writing and approval of the final version of the manuscript, and are responsible for all aspects of the research, including ensuring its accuracy and completeness.

of Congenital Malformations. Birth Defects Res. 2018; 110 (2): 87-91.

5. Feldkamp ML, Carey JC, Byrne JLB, Krikov S, Botto LD. Etiology and clinical presentation of birth defects: population based study. BMJ. 2017; 357: j2249. Disponível em: http://www.bmj.com/lookup/doi/10.1136/bmj.j2249.

6. United Nations Inter-agency Group for Child Mortality Estimation (UN IGME), 'Levels \& Trends in Child Mortality: Report 2017, Estimates Developed by the UN Inter-agency Group for Child Mortality Estimation', United Nations Children's Fund, New York [Internet]. 2017. Disponível em: https://www.unicef.org/publications/files/ Child_Mortality_Report_2017.pdf.

7. Brasil. Ministério da Saúde. Secretaria de Vigilância em Saúde. Departamento de Vigilância de Doenças e Agravos Não Transmissíveis e Promoção da Saúde. Saúde Brasil 
2015/2016 : uma análise da situação de saúde e da epidemia pelo vírus Zika e por outras doenças transmitidas pelo Aedes aegypti; 2017.

8. Matthews TJ, MacDorman MF, Thoma ME. Infant Mortality Statistics From the 2013 Period Linked Birth/Infant Death Data Set. Natl Vital Stat Rep [Internet]. 2015 Aug 6; 64 (9): 1-30. Disponível em: http://www.ncbi.nlm.nih.gov/pubmed/26270610.

9. Sierra Romero M del C, Hernández EN, Serrano SC, Pablo AER, Hernández JV. Prevalencia del síndrome de Down en México utilizando los certificados de nacimiento vivo y de muerte fetal durante el periodo 2008-2011. Bol Med Hosp Infant Mex. 2014; 71 (5): 292-7.

10. Organização Panamericana de Saúde. OPAS / OMS insta países das Américas a reforçar vigilância de microcefalia e outras anomalias congênitas [Internet]. OPAS. 2016 [citado em 2018 maio 2]. Disponível em https://www.paho.org/bra/index.php?option=com_content \&view=article \&id=5012:opas-oms-insta-paises-das-americas-a-reforcar-vigilancia-de-microcefalia-e-outras-anomalias-congenitas $\&$ Itemid $=812$

11. Nhoncanse GC, Melo DG. Confiabilidade da Declaração de Nascido Vivo como fonte de informação sobre os defeitos congênitos no Município de São Carlos, São Paulo, Brasil Ciên Saúde Coletiva. 2012 Apr; 17 (4): 955-63. Disponível em: http://www.scielo.br/scielo.php?script=sci_arttext\&pid $=\mathrm{S} 1413-81232012000400017 \& \operatorname{lng}=\mathrm{pt} \& \operatorname{lng}=\mathrm{pt}$.

12. Maia LTS, Souza WV, Mendes ACG, Silva AGS. Uso do linkage para a melhoria da completude do SIM e do Sinasc nas capitais brasileiras. Rev Saúde Pública. 2017; 51: 112. Disponível em: https://www.revistas.usp.br/rsp/article/ view/141551.

13. Marques LJP, Oliveira CM, Bonfim CV. Avaliação da completude e da concordância das variáveis dos Sistemas de Informações sobre Nascidos Vivos e sobre Mortalidade no Recife-PE, 2010-2012. Epidemiol Serv Saúde. 2016; 25 (4): 849-54.

14. Kropiwiec MV, Franco SC, Amaral AR. Fatores associados à Mortalidade Infantil em município com índice de desenvolvimento humano elevado. Rev Paul Pediatr. 2017; 35 (4): 391-8.

15. Boulet SL, Shin M, Kirby RS, Goodman D, Correa A. Sensitivity of Birth Certificate Reports of Birth Defects in Atlanta, 1995-2005: Effects of Maternal, Infant, and Hospital Characteristics. Public Health Rep. 2011; 126 (2): 186-94.

16. População estimada: IBGE, Diretoria de Pesquisas, Coordenação de População e Indicadores Sociais, Estimativas da população residente com data de referência 1o de julho de 2016.

17. Oliveira MM, Andrade SSC, Dimech GS, Oliveira JCG, Malta DC, Rabello Neto DL, Moura L. Avaliação do Sistema de Informações sobre Nascidos Vivos. Brasil, 2006 a 2010. Epidemiol Serv Saúde. 2015; 24 (4): 629-40.

\footnotetext{
Received on September 28, 2018

Final version presented on August 26, 2019

Approved on September 2, 2019
}

18. Fantin C, Santos ML, Carvalho LB, Gomes NM, Souza N, Sousa GB. Estudo das anomalias cromossômicas ocorridas em uma maternidade nos anos de 2010 a 2014. 2017; 22: 18.

19. Salemi JL, Tanner JP, Sampat DP, Rutkowski RE, Anjohrin SB, Marshall J, Kirby RS. Evaluation of the Sensitivity and Accuracy of Birth Defects Indicators on the 2003 Revision of the U.S. Birth Certificate: Has Data Quality Improved? Paediatr Perinat Epidemiol. 2017; 31 (1): 67-75.

20. Tanner JP, Salemi JL, Hauser KW, Correia JA, Watkins SM, Kirby RS. Birth defects surveillance in Florida: Infant death certificates as a case ascertainment source. Birth Defects Res Part A Clin Mol Teratol. 2010; 88 (12): 1017-22.

21. Geremias AL, Almeida MF, Flores LPO. Avaliação das declarações de nascido vivo como fonte de informação sobre defeitos congênitos. Rev Bras Epidemiol. 2009; 12 (1): $60-8$

22. Willian Cosme H, Lima LS, Barbosa LG. Prevalence of congenital anomalies and their associated factors in newborns in the city of São Paulo from 2010 to 2014. Rev Paul Pediatr. 2017; 35 (1): 33-8.

23. Lima ID, Araújo AA, Medeiros WMC, Rodrigues JM, Feitosa MM, Silva RB, Maia EFT, Wingerter DG. Perfil dos óbitos por anomalias congênitas no Estado do Rio Grande do Norte no período de 2006 a 2013. Rev Ciênc Med Biol. 2017; 16 (1): 52-8.

24. Fontoura FC, Cardoso MVL. Associação das malformações congênitas com variáveis neonatais e maternas em unidades neonatais numa cidade do nordeste brasileiro. Texto Context Enferm. 2014; 1 (4): 907-14.

25. Rodrigues LS, Lima RHS, Costa LC, Batista RFL. Características das crianças nascidas com malformações congênitas no município de São Luís, Maranhão, 20022011. Epidemiol Serv Saúde. 2014; 23 (2): 295-304.

26. Catarino CF, Gomes MA de SM, Gomes SC dos S, Magluta C. Registros de cardiopatia congênita em crianças menores de um ano nos sistemas de informações sobre nascimento, internação e óbito do estado do Rio de Janeiro, 2006-2010. Epidemiol Serv Saúde. 2017; 26 (3): 535-43.

27. Anderka M, Mai CT, Romitti PA, Copeland G, Isenburg J, Feldkamp ML, Krikov S, Rickard R, Olney RS, Canfield MA, Stanton C, Mosley B, Kirby RS. Development and implementation of the first national data quality standards for population-based birth defects surveillance programs in the United States. BMC Public Health. 2015; 15 (1): 925.

28. European Survillance of Congenital Anomalies. What Is EUROCAT? [Internet]. 2018 [citado em 2018 maio 3]. Disponível em: http://www.eurocat-network.eu/aboutus/ whatiseurocat/whatiseurocat.

29. Mai CT, Kirby RS, Correa A, Rosenberg D, Petros M, Fagen MC. Public health practice of population-based birth defects surveillance programs in the United States. J Public Heal Manag Pract. 2016; 22 (3): E1-8.

30. Estudo Colaborativo Latino-Americano de Malformações Congênitas [Internet]. 2018 [citado em 2018 maio 2]. Disponível em: http://www.eclamc.org/port/index.php. 